\title{
Invasive and noninvasive methods for studying pulmonary function in mice
}

\author{
Thomas Glaab¹, Christian Taube ${ }^{1}$, Armin Braun*2 and Wayne Mitzner ${ }^{3}$
}

Address: ${ }^{1}$ Department of Pulmonary Medicine, III. Medical Clinic, Johannes Gutenberg-University, Mainz, Germany, ${ }^{2}$ Fraunhofer Institute of Toxicology and Experimental Medicine (ITEM), Hannover, Germany and ${ }^{3}$ Division of Physiology, Bloomberg School of Public Health, Johns Hopkins University, Baltimore, Maryland 21205, USA

Email:Thomas Glaab - thomasglaab@web.de; Christian Taube - taube@3-med.klinik.uni-mainz.de; Armin Braun* - braun@item.fraunhofer.de; Wayne Mitzner - wmitzner@jhsph.edu

* Corresponding author

Published: 14 September 2007

Respiratory Research 2007, 8:63 doi:10.1 186/1465-992I-8-63

This article is available from: http://respiratory-research.com/content/8/I/63

This is an Open Access article distributed under the terms of the Creative Commons Attribution License (http://creativecommons.org/licenses/by/2.0), which permits unrestricted use, distribution, and reproduction in any medium, provided the original work is properly cited.

\begin{abstract}
The widespread use of genetically altered mouse models of experimental asthma has stimulated the development of lung function techniques in vivo to characterize the functional results of genetic manipulations. Here, we describe various classical and recent methods of measuring airway responsiveness in vivo including both invasive methodologies in anesthetized, intubated mice (repetitive/non-repetitive assessment of pulmonary resistance $\left(R_{L}\right)$ and dynamic compliance $\left(C_{\text {dyn }}\right)$; measurement of low-frequency forced oscillations (LFOT)) and noninvasive technologies in conscious animals (head-out body plethysmography; barometric whole-body plethysmography). Outlined are the technical principles, validation and applications as well as the strengths and weaknesses of each methodology. Reviewed is the current set of invasive and noninvasive methods of measuring murine pulmonary function, with particular emphasis on practical considerations that should be considered when applying them for phenotyping in the laboratory mouse.
\end{abstract}

\section{Background}

The widespread use of genetically altered mouse models of experimental asthma has stimulated the development of lung function techniques in vivo to characterize the functional results of genetic manipulations. The ability to determine in vivo the respiratory function in laboratory mice is of great interest because of the prominent role played by these animals in biomedical, pharmacological and toxicological research. Mice are, at present, the preferred species used as an experimental model of allergic airway disease. This is largely due to a number of advantages including a well characterized genome and immune system, short breeding periods, the availability of inbred and transgenic strains, suitable genetic markers, the ability to readily induce genetic modifications and pragmatically, relatively low maintenance costs. The development of viable mouse models has largely contributed to a better understanding of the pathomechanisms underlying allergic airway inflammation and airway hyperresponsiveness (AHR) [1-3].

To fully explore the value of mouse models of experimental asthma, however, it is necessary to develop sensitive physiological methodologies that allow the quantitative assessment of airway responsiveness in intact organisms. Measurement of pulmonary function in mice clearly presents significant challenges due to the small size of their airways. In recent years, considerable progress has been made in developing valid and suitable measures of mouse lung function. Accordingly, several different inva- 
sive and noninvasive lung function techniques have been developed to characterize the phenotype of experimental models of lung disease [4-7]. Table 1 lists some of the principal advantages and limitations of invasive and noninvasive lung function methods.

It is important to recognize that each approach represents a compromise between accuracy, noninvasiveness, and convenience. As a result, a correlation exists between the invasiveness of a measurement technique and its precision [8]. The less invasive a measurement, the less likely it is to produce consistent, reproducible and meaningful data.

Invasive monitoring of lung function using parameters such as pulmonary resistance $\left(R_{L}\right)$ or dynamic compliance $\left(\mathrm{C}_{\mathrm{dyn}}\right)$ is the classical method for accurate and specific determination of pulmonary mechanics. $\mathrm{R}_{\mathrm{L}}$ is the sum of airway (Raw) and tissue (Rti) resistance, which are fairly comparable at normal breathing rate. Drawbacks of conventional invasive methodologies particularly include the surgical instrumentation of the trachea thus often excluding the practicality of repeated measurements. Modifications of the invasive approach involving orotracheal intubation, however, now have enabled repetitive monitoring of pulmonary mechanics in anesthetized, spontaneously breathing mice $[9,10]$. This approach still requires anesthesia as well as a good deal of technical skill to achieve reproducible consistency.

Even more detailed measurements of pulmonary mechanics can be obtained with the low-frequency forced oscillation technique (LFOT) $[4,11]$. In mice, LFOT is applied in anesthetized, paralyzed, tracheostomized animals to measure the complex input impedance $(Z)$ of the lungs. The low-frequency impedance $(Z)$ reflects the characteristically different frequency dependencies of the airway and tissue compartments. One of the major advantages of this approach is the ability to differentiate between airway and tissue mechanics in the lung.

To circumvent the significant technological challenges associated with direct measurements of pulmonary mechanics in mice, more convenient but less specific noninvasive plethysmographic methods have been studied in conscious animals $[4,5,10,12,13]$.

This report attempts to review some of the invasive and noninvasive technologies currently used for measuring pulmonary function in intact mice with special attention to practical considerations. This review reflects our own practical experience with several different currently used lung function methods in mice. In this context, we describe the different technologies including their experimental validations, practical applications, as well as the feasibility and limitations of each methodology.

Invasive methods for studying pulmonary function in mice Techniques used to directly measure pulmonary mechanics in mice represent the "gold standard", but generally require anesthesia, intubation and expertise in handling.

\section{Determination of pulmonary resistance $\left(R_{L}\right)$ and dynamic compliance $\left(C_{d y n}\right)$ in tracheostomized and mechanically ventilated mice}

The classical approach to determine lung function in mice is the measurement of pulmonary resistance $\left(\mathrm{R}_{\mathrm{L}}\right)$ and dynamic compliance $\left(\mathrm{C}_{\mathrm{dyn}}\right)$ in response to non-specific

Table I: Principal advantages and drawbacks of invasive and noninvasive methods

\begin{tabular}{|c|c|c|}
\hline Method & Pros & cons \\
\hline \multirow[t]{7}{*}{ Invasive } & - sensitive and specific analysis of pulmonary mechanics & $\begin{array}{l}\text { - technically demanding (instrumentation of the trachea, } \\
\text { technical equipment) }\end{array}$ \\
\hline & - based on physiological principles & - need for anesthesia and tracheal instrumentation \\
\hline & - intact anatomical relationships in the lung & - time-consuming \\
\hline & $\begin{array}{l}\text { - bypassing of upper airway resistance, controlled ventilation, } \\
\text { and local administration of aerosols via the tracheal tube }\end{array}$ & - no repetitive measurements in tracheostomized animals \\
\hline & - ease of broncho-alveolar lavage samplings & - expertise in handling \\
\hline & $\begin{array}{l}\text { - repetitive and long-term measurements in orotracheally } \\
\text { intubated mice }\end{array}$ & \\
\hline & $\begin{array}{l}\text { - applicable to the assessment of obstructive and restrictive* } \\
\text { lung disorders (*requires additional hard- and software) }\end{array}$ & \\
\hline \multirow[t]{4}{*}{ noninvasive } & - quick, easy-to-handle & - no direct assessment of pulmonary mechanics \\
\hline & $\begin{array}{l}\text { - repetitive and/or longitudinal measurements of airway } \\
\text { responsiveness in the same animal }\end{array}$ & - prone to artifacts (movements, temperature) \\
\hline & $\begin{array}{l}\text { - normal breathing pattern with no need for anesthesia or } \\
\text { tracheal instrumentation }\end{array}$ & $\begin{array}{l}\text { - contribution of upper airway resistance (changes of glottal } \\
\text { aperture, nasal passages) }\end{array}$ \\
\hline & & $\begin{array}{l}\text { - uncertainty about the exact magnitude and localization of } \\
\text { bronchoconstriction }\end{array}$ \\
\hline
\end{tabular}


bronchoconstrictors. In 1988 Martin et al. demonstrated the feasibility of $\mathrm{R}_{\mathrm{L}}$ and $\mathrm{C}_{\mathrm{dyn}}$ measurement in anesthetized, tracheotomized and mechanically ventilated mice [14]. To assess $R_{L}$ and $C_{\text {dyn }}$ determination of transpulmonary pressure and flow are required. In mice the chest wall has been shown to present little mechanical load compared to the mechanical load of the lung [15], unless there is some pathology of the chest wall. Thus direct measurement of transpulmonary pressure is generally not mandatory [16]. Tidal flow is commonly derived from the differentiation of the volume signal. $\mathrm{R}_{\mathrm{L}}$ and $\mathrm{C}_{\mathrm{dyn}}$ can then be calculated by fitting an equation of motion to the measurements of pressure, flow and volume [4]. In this equation, $\mathrm{P}_{\mathrm{TP}}=\mathrm{V} \times \mathrm{R}_{\mathrm{L}}+\mathrm{VT} / \mathrm{C}_{\mathrm{dyn}} \mathrm{P}_{\mathrm{TP}}$ is transpulmonary pressure (or in the mouse $\approx$ transrespiratory pressure), $\mathrm{V}$ is tidal airflow, $\mathrm{R}_{\mathrm{L}}$ is pulmonary resistance, $\mathrm{V}_{\mathrm{T}}$ is tidal volume, and $\mathrm{C}_{\mathrm{dyn}}$ is the dynamic pulmonary compliance. The invasive measurement of $\mathrm{R}_{\mathrm{L}}$ and $\mathrm{C}_{\mathrm{dyn}}$ by body plethysmography normally requires surgical instrumentation of the trachea in anesthetized animals. It is common to use pentobarbital sodium $(70-90 \mathrm{mg} / \mathrm{kg})$ administered intraperitoneally as anesthetic because it normally provides an adequate depth of anesthesia for at least 30 minutes. Alternative anesthetic regimens in mice have been described [6,7]. It is important not to disturb and agitate the animal beforehand, as this may impact the quality of the subsequent measurement. Useful reflexes to ensure that an adequate depth of anesthesia has been attained include loss of the righting reflex (lost during the onset of anesthesia) and of the toe-pinch reflex (lost during medium to deep anesthesia). If the animal attempts to withdraw its limb, then it is not sufficiently anesthetized and should be administered an additional dose ( $10_{-}$ $20 \%$ of the initial dose).

Determination of $\mathrm{R}_{\mathrm{L}}$ and $\mathrm{C}_{\mathrm{dyn}}$ not only provides the classical determination of airway responsiveness, but also provides a more detailed insight into pulmonary mechanics. $\mathrm{R}_{\mathrm{L}}$ reflects both narrowing of the conducting airways and parenchymal viscosity. In contrast $\mathrm{C}_{\mathrm{dyn}}$ is considered to primarily reflect the elasticity of the lung parenchyma, but is also influenced by surface tension, smooth muscle contraction and peripheral airway inhomogeneity. Numerous methods for determining $\mathrm{R}_{\mathrm{L}}$ and $\mathrm{C}_{\mathrm{dyn}}$ have been described in anesthetized and instrumented mice $[4,5,7]$. One option is to use a (mass-constant) body plethysmography box with the tracheal cannula leading out of the plethysmograph $[17,18]$. When mechanical ventilation is indicated, tracheostomy is usually performed for endotracheal intubation of the deeply anesthetized animal. The surgically exposed trachea is viewed directly and the incision is made in the upper third of the trachea to allow proper insertion of the cannula and to avoid measuring artifacts.
The tracheostomy tube can then be attached to a four-way connector, where two ports of the connector are attached to the inspiratory and expiratory sides of a ventilator and the remaining tube to a pressure transducer that measures tracheal pressure. Ventilation should then be set at a rate comparable to normal breathing (around 150 breaths/ min, tidal volume $\approx 8-10 \mathrm{ml} / \mathrm{kg}$ ) with a positive endexpiratory pressure (PEEP) of $2-5 \mathrm{~cm} \mathrm{H}_{2} \mathrm{O}$. It is important to use PEEP in mice even with the chest closed, since functional residual capacity (FRC) in conscious mice is normally maintained with active inspiratory muscle tone that is minimal or eliminated in the anesthetized animal [16]. Lung volume changes must be assessed by calibrating the plethysmographic pressure. To stabilize the volume signal for thermal drift the body plethysmograph chamber can be connected to a large bottle filled with copper gauze.

To assess airway responsiveness, cholinergic bronchoconstrictive agents such as methacholine $(\mathrm{MCh})$ are administered to the animal at increasing doses either by aerosol inhalation or systemically by intravenous administration via the tail or jugular vein. Airway responsiveness is assessed either as the change in $\mathrm{R}_{\mathrm{L}}$ compared to baseline or as the peak response after challenge. Before each series of challenge doses the lung should be briefly hyperinflated to standardize the volume history. Measurements are made of the absolute values of the responses of $C_{d y n}$ and $R_{L}$ and as a percentage of baseline, determined from an initial vehicle challenge.

The key advantage of the invasive approach is the reproducible and precise assessment of transient changes in pulmonary mechanics in mice. The insertion of a tracheal tube also avoids measurement of changes in the upper airways, and provides the opportunity for taking bronchoalveolar lavage (BAL) samples after lung function measurements. Disadvantages of conventional invasive measurements include surgical tracheostomy thus precluding repeated measurements, the need for anesthesia, mechanical ventilation and expertise in handling.

\section{Repetitive assessment of $R_{L}$ and $C_{d y n}$ in orotracheally intubated mice}

As outlined above, the utility of invasive determination of murine lung function is generally limited by several factors. Recent methodological advances, however, have improved the ability to measure lung mechanics on repeated occasions [19]. These modifications involving direct laryngoscopy have now enabled repetitive determination of pulmonary mechanics $\left(\mathrm{R}_{\mathrm{L}}\right.$ and $\left.\mathrm{C}_{\mathrm{dyn}}\right)$ in combination with local aerosol administration via an orotracheal tube in intact animals $[9,10,20]$.

With one of these approaches, intubation is done with a standard 20G $\times 32 \mathrm{~mm}$ (1 $1 / 4$ inch) teflon cannula (e.g. 
Abbocath ${ }^{\circledast}$-T cannula, Abott, Ireland) in anesthetized mice that are suspended by their upper incisors from a rubber band and the midthorax held by an elastic band on a $65^{\circ}$ incline Plexiglas support to facilitate intubation. We have made positive experience using anesthesia plus analgesia with $20-30 \mathrm{mg} / \mathrm{kg}$ etomidate and $0.05 \mathrm{mg} / \mathrm{kg}$ fentanyl given intraperitoneally (i.p) with minimal supplementations as required or volatile anesthesia with halothane $1.5 \%$ plus propofol $70 \mathrm{mg} / \mathrm{kg}$ i.p. Paralysis is not mandatory. A metal laryngoscope (length $12 \mathrm{~cm}$ plus an additional $1.8 \mathrm{~cm}$ at an angle of $135^{\circ}$, with $0.3 \mathrm{~cm}$ ) is used as a tool to allow visualization of the tracheal opening which is transilluminated below the vocal cords by a halogen light source. The direct visualization of the trachea allows gentle insertion of the cannula into the tracheal opening $[19,21]$. Orotracheal intubation of the anesthetized mouse takes about five minutes and has also been successfully applied in mouse cardiac surgery [21]. Alternatively, a Seldinger technique has been described using a $0.5 \mathrm{~mm}$ optical light fiber as an introducer over which the cannula is slid down into the proximal trachea [22]. The intubated, spontaneously breathing animal is then placed in supine position in a thermostat-controlled whole-body plethysmograph (Figure 1). The orotracheal tube is directly attached to a pneumotachograph/differential pressure transducer unit to record tidal flow. To measure transpulmonary pressure (РTP), a water-filled polyethylene (PE)-90 tubing is inserted into the esophagus to the level of the midthorax and attached to a pressure transducer. $\mathrm{R}_{\mathrm{L}}$ and $\mathrm{C}_{\mathrm{dyn}}$ are calculated over a complete respiratory cycle with an integration method over flows, volumes and pressure $[10,23]$. The resistance of the orotracheal tube $\left(0.63 \mathrm{~cm} \mathrm{H}_{2} \mathrm{O} \cdot \mathrm{s} \cdot \mathrm{ml}^{-1}\right)$ is subtracted from $\mathrm{R}_{\mathrm{L}}$ recordings.

This approach was validated in several groups of BALB/c mice [10]. The results showed that dose-related increases in $\mathrm{R}_{\mathrm{L}}$ and $\mathrm{C}_{\mathrm{dyn}}$ to inhaled cholinergic challenge with $\mathrm{MCh}$ were reproducible over short and extended intervals without causing significant cytological alterations in the BAL fluid or relevant histological changes in the proximal trachea and larynx regardless of the number of orotracheal intubations.

A key advantage of this method which combines orotracheal intubation via direct laryngoscopy and local administration of aerosols directly into the lung is the repetitive assessment of classical measures of pulmonary mechanics to defined inhalation challenges in intact individual mice. Because the orotracheal cannula is tapered, a tight seal develops as it is inserted into the proximal trachea. This enables use of this method in spontaneously breathing as well as in mechanically ventilated mice. Orotracheal intubation further offers the opportunity to collect BAL samples in vivo on multiple occasions in the same animals

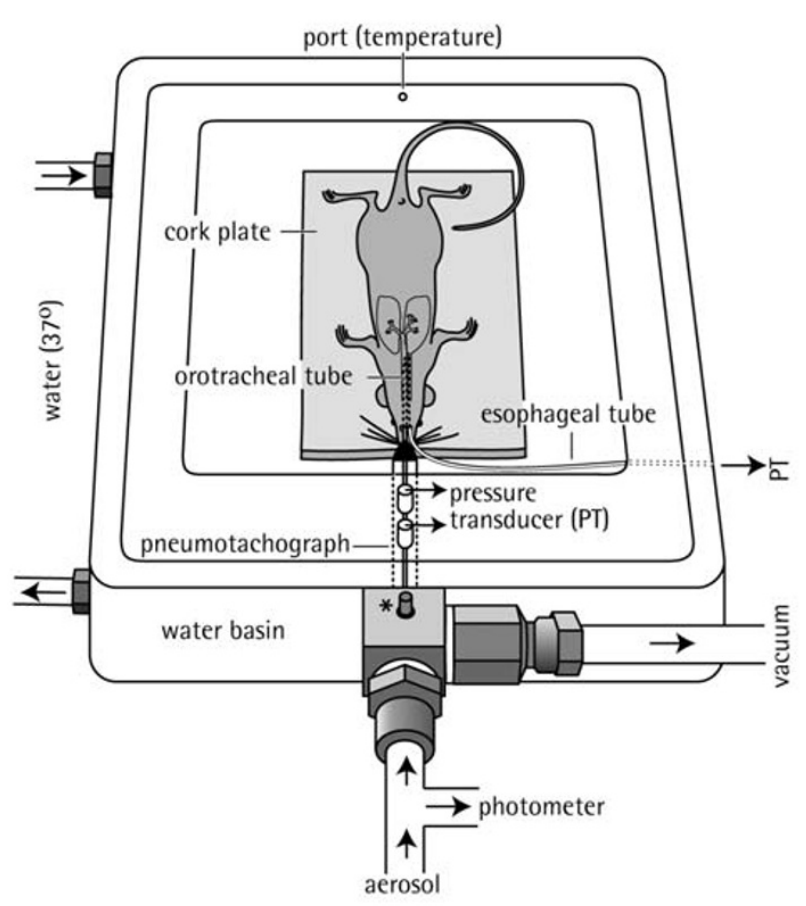

\section{Figure I}

Diagram of the plethysmograph used for pulmonary function testing of anesthetized, orotracheally intubated mice. A thermostat-controlled water basin $\left(37^{\circ} \mathrm{C}\right)$ built in the plethysmograph chamber ensured a body temperature of $34-35^{\circ} \mathrm{C}$ as measured by rectal thermometer.

Defined aerosol concentrations of methacholine, as measured by an aerosol photometer, were delivered into the airways via the orotracheal tube. For calculation of pulmonary resistance $\left(R_{L}\right)$, transpulmonary pressure $\left(P_{T P}\right)$ was recorded via an esophageal tube, and tidal flow was determined by a pneumotachograph attached directly to the orotracheal tube. PT, pressure transducer. Taken from [10] with permission.

[24]. Limitations include the need for anesthesia, instrumentation of the trachea and expertise in handling.

\section{Low-frequency forced oscillation technique}

Another approach for invasive assessment of airway function in mice is the low-frequency forced oscillation technique (LFOT). The LFOT was derived from similar techniques used in humans and larger animals and produces estimates of lung impedance $(Z)$ which can be considered the most detailed measurement of pulmonary mechanics currently available $[4,8,11,25,26]$.

Different parts of the impedance frequency spectrum reflect different parts of the respiratory system. Impedance data can be further analyzed using the Constant Phase Model which provides a suitable assessment of pulmonary mechanics [27]. Fitting the Constant Phase Model to 
oscillatory data allows airway and tissue mechanical components to be distinguished.

Until recently, little was known about lung impedance of mice, particularly because of technical difficulties of measuring lung impedance precisely. Lung impedance consists of two parts. One part of impedance, resistance (R), describes essentially the resistance of the conducting airways (Raw) and tissue (Rti). The second part of impedance, referred to as reactance $(\mathrm{X})$, reflects respiratory compliance (1/elastance) and characterizes the lung parenchyma. The contribution of the inertance (I) of the gas in the murine airways, however, is only significant at frequencies $\geq 20 \mathrm{~Hz}$. The main advantage of this approach for measuring lung function, compared to the classical methods of assessing airway resistance and dynamic compliance, is that the more sophisticated mathematical models may better represent the complexity of the intact lung.

Two different methods have been developed to assess lung impedance in small animals. One technique uses a small plastic wave tube that is placed into the trachea and is attached to a loudspeaker $[4,28]$.

The properly miniaturized wave tube has a precisely known geometry and material constant. During the measurement ventilation is paused and the setting is switched from the ventilation to the measurement circuit. The loudspeaker produces an oscillatory flow through the tube and lung impedance is assessed from flow and pressure measurements along the tube. From the pressure spectra along the tube lung impedance can be assessed [29]. This technique is particularly useful for the precise measurement in very young mice, where other techniques such as the piston pump oscillator may be critical [30]. The second method uses a computer-controlled piston pump. This system not only allows for mechanical ventilation of the animal but also for precise frequency and amplitude control of the applied oscillations. The constant phase model is then fit to the data obtained from the multiple frequencies simultaneously applied at the airway opening, thereby enabling determination of the airway and lung tissue impedance. This model involves three independent variables: airway resistance $(R)$ as a marker of central airway resistance, tissue damping (G) is related to tissue resistance and reflects the dissipative properties, while tissue elastance $(\mathrm{H})$ describes the elastic properties of the lung tissue.

LFOT correlates well with classical measures of lung resistance and has been successfully used to assess airway responsiveness in mouse models of allergic airway disease $[4,15,25,28,31-33]$. The computer-controlled ventilator also allows the assessment of quasi-static compliance. As with other invasive techniques, the animals need to be anesthetized, tracheally intubated and then connected to the computer-controlled ventilator (e.g. set at a rate of 150 breaths per minute and a tidal volume of $10 \mathrm{ml} / \mathrm{kg}$ ), with application of 2-5 $\mathrm{cm} \mathrm{H}_{2} \mathrm{O}$ PEEP. Mice can then be challenged with bronchoconstrictors by inhalation or via intravenous routes. It should be considered that while LFOT can be employed during apnea only, paralysis is not mandatory in anesthetized mice.

The main advantage of this technique is the detailed analysis of airway function and particularly the clear distinctions between central airways and more peripheral changes. This approach, however, also shares similar disadvantages with other invasive techniques as shown in Table 1 . In addition, at least for assessing airway hyperresponsiveness it is still unclear what additional value lung impedance recordings provide over simpler measures of pulmonary mechanics [34].

\section{Noninvasive methods for studying pulmonary function in mice}

Noninvasive plethysmographic methods of monitoring pulmonary function are preferred for long-term serial study designs as well as for screening large numbers of conscious mice. In many instances, a combination of invasive and noninvasive techniques is required to fully understand the physiologic significance of a respiratory phenotype.

\section{Barometric whole-body plethysmography}

In barometric whole-body plethysmography mice are placed in a closed chamber and the pressure fluctuations that occur during the breathing cycle are recorded [35]. In contrast to invasive measurements of airway function animals are neither anesthetized nor instrumented and are relatively unrestrained. The major benefit of this noninvasive technique is that repetitive measurements can be done in the same mouse. Using a pressure transducer the pressure differences between the main chamber of the plethysmograph where the animal is placed and a reference chamber are assessed (Figure 2).

From this pressure time curve several parameters can be determined including breathing frequency, inspiratory and expiratory time as well as the maximum box pressure during inspiration and expiration. None of these variables is specific nor sensitive enough for being a suitable marker of airway responsiveness. From the box pressure signal during inspiration and expiration, and the timing comparison of early and late expiration, a dimensionless parameter called "enhanced pause" (Penh) has been calculated. It is notable that we do not refer to the as yet nonvalidated method of measuring Penh in freely moving mice. 


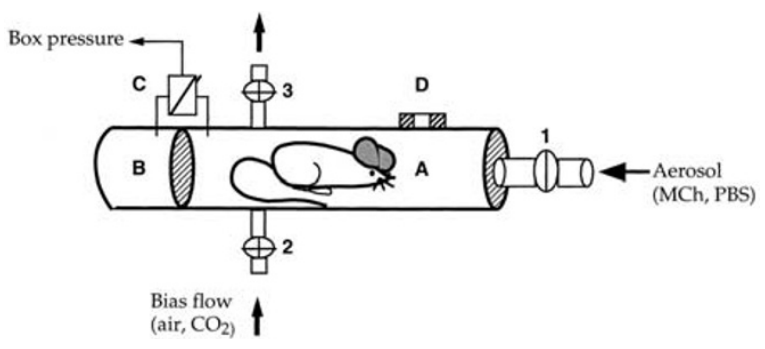

\section{Figure 2}

Diagram of the barometric whole-body plethysmograph (taken from [35] with permission). (A) Main chamber containing the animal $(B)$ connected to a pressure transducer (C) which is also connected to the reference chamber (B).

(D) Pneumotachograph. Main inlet for aerosol. The bias airflow at $0.2 \mathrm{~L} / \mathrm{min}$ was discontinued during aerosol challenges.

To monitor responsiveness mice are exposed to a nebulized bronchoconstrictor such as $\mathrm{MCh}$ and changes in Penh are recorded for $\sim 2-5$ minutes for each aerosol challenge. Usually the response is expressed as fold increase of Penh for each MCh concentration compared with Penh values after an initial buffer challenge with the aerosolized vehicle.

Early studies in mice and other species showed a correlation between changes in Penh following methacholine challenge and lung function parameters determined by invasive lung function measurements and the technique has been widely used [18,36-39]. Based on this early work and because of the convenient handling of the animals, this method gained popularity in many research labs. An increasing amount of observations, however, have now cast doubt on the validity of Penh to reflect airway narrowing. Several reports found discrepancies in the amount of airway responsiveness when comparing Penh to conventional parameters of pulmonary mechanics [40-42]. Further evaluation of Penh demonstrated that events completely unrelated to lung mechanics such as humidification and warming of inspired gas, hyperoxia, and the timing of ventilation, have a major effect on the measurement $[31,41]$. These more careful and theoretical findings have thus led to a justifiable scepticism for using Penh as a reliable marker of airway obstruction [43-45].

Nevertheless, in principle and consistent with current cautionary warnings, Penh may be useful for gross screening of overall lung function in small animals [43]. Seen by itself, however, Penh says nothing about airway responsiveness and researchers who use it should corroborate the measurements with parallel, independent direct measurements of pulmonary mechanics $[5,7,44,45]$. Pros and cons of this method are summarized in Table 2 .

\section{Head-out body plethysmography}

Recent emphasis on the benefits of noninvasive technology has renewed interest in analyzing expiratory tidal flow patterns as a tool in the assessment of airway obstruction. Although noninvasive measurement of murine respiratory function has virtually become synonymous with the widely used barometric whole-body plethysmography method [35], some other noninvasive methods have been described [13,46-48].

The noninvasive measurement of midexpiratory flow $\left(\mathrm{EF}_{50}\right)$ as measured by head-out body plethysmography (Figure 3) was first described as an appropriate instrument to measure airway responsiveness in conscious mice by Alarie et al [48]. With this method, airway constriction induces characteristic changes in the tidal flow pattern, which are best revealed by a decrease in tidal midexpiratory flow $\left(\mathrm{EF}_{50},[\mathrm{ml} / \mathrm{s}]\right)$ (Figure 4$)$. The change in $\mathrm{EF}_{50}$ is
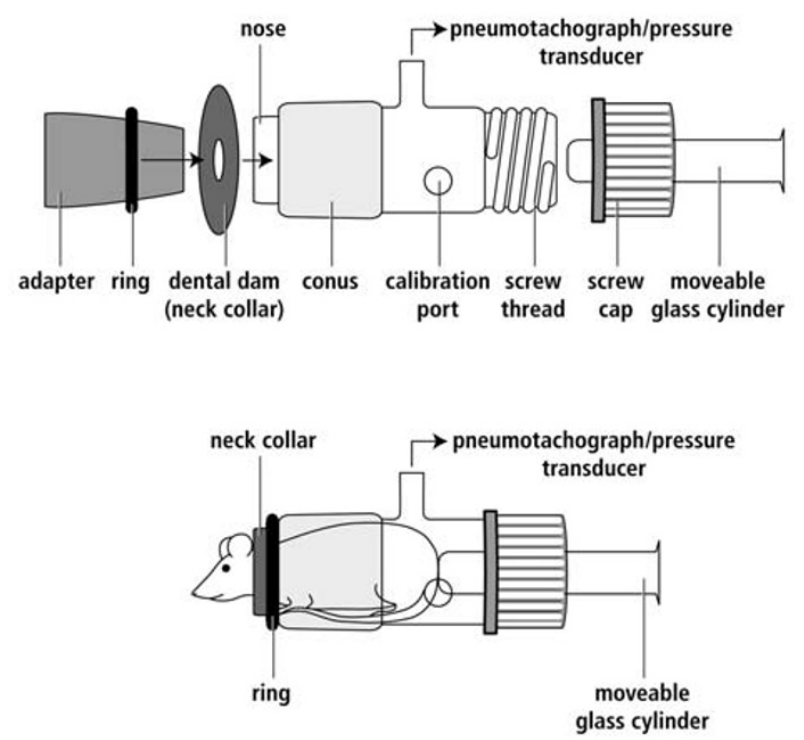

\section{Figure 3}

Schematic drawing of the head-out body plethysmograph. The figure illustrates the attachment of the neck collar (made of dental dam with a central hole of 7-8 $\mathrm{mm}$ for a 20-25 g mouse) to the plethysmograph. The adapter is put in the front opening of the plethysmograph and a viscoelastic ring is slipped over the fixed rubber dam at the nose of the plethysmograph thus fixing the collar. The conscious animal is then placed in the glass plethysmograph and attached via the conus to a ventilated head exposure chamber. A moveable glass cylinder built in the screw cap enables atraumatic positioning of the mouse. Volume calibration (I-I.5 ml air) of the plethysmograph (front and back opening sealed) is done before each measurement. Before data collection, mice are allowed to acclimatize for at least about 10 minutes in the body plethysmographs. 
Table 2: Pros and cons of noninvasive barometric whole-body plethysmography

\begin{tabular}{ll}
\hline \multicolumn{1}{c}{ pros } & \multicolumn{1}{c}{ cons } \\
\hline $\begin{array}{l}\text { - minimal restraint of the } \\
\text { animal }\end{array}$ & $\begin{array}{l}\text { • enhanced pause as an empirically } \\
\text { derived value with unclear physiological } \\
\text { relevance } \\
\text { • influenced by a number of factors } \\
\text { unrelated to bronchoconstriction } \\
\text { • potential to overestimate or } \\
\text { underestimate the real degree of airway } \\
\text { responsiveness } \\
\text { - data need to be confirmed by invasive } \\
\text { methodology }\end{array}$ \\
\hline
\end{tabular}

typically linked with a reduction in tidal volume (VT), breathing rate (f) and prolonged expiratory time (TE). $\mathrm{EF}_{50}$ can be determined with a glass head-out body plethysmography system. Animals are gently placed in the body plethysmographs while the head of each animal protrudes through a neck collar into a ventilated head exposure chamber. Aerosols can be delivered directly through the head exposure chamber. Tidal flow measurement is made with a calibrated pneumotachograph and a differential pressure transducer attached to the top port of each body chamber. The amplified and digitized flow signals are integrated with time to obtain tidal volume. From these signals several standard respiratory parameters, including tidal volume, breathing frequency, time of inspiration and expiration, and $\mathrm{EF}_{50}$ can be derived from software analysis.

Validation studies in mice have demonstrated that the decline in $\mathrm{EF}_{50}$ to inhaled cholinergic and allergic challenge closely reflects the decreases in simultaneously recorded pulmonary conductance $\left(\mathrm{G}_{\mathrm{L}}=1 / \mathrm{R}_{\mathrm{L}}\right)$ and dynamic compliance $\left(\mathrm{C}_{\text {dyn }}\right)$ [10]. The $\mathrm{EF}_{50}$ method has been applied in several experimental situations, including animal models of experimental asthma, post-pneumonectomy, hyperoxia, and to study the effects of airborne

Table 3: Pros and cons of noninvasive tidal midexpiratory flow measurement

\begin{tabular}{|c|c|}
\hline pros & cons \\
\hline - based on physiological principles & $\begin{array}{l}\text { - underestimation of the } \\
\text { magnitude of airway } \\
\text { responsiveness as compared with } \\
\text { direct measures of pulmonary } \\
\text { mechanics }\end{array}$ \\
\hline $\begin{array}{l}\text { - acceptable agreement with } \\
\text { simultaneous invasive } \\
\text { measurements of pulmonary } \\
\text { mechanics }\end{array}$ & - restraint by neck collar \\
\hline $\begin{array}{l}\text { - physical meaning enables } \\
\text { comparability of data from animal } \\
\text { to animal }\end{array}$ & \\
\hline
\end{tabular}
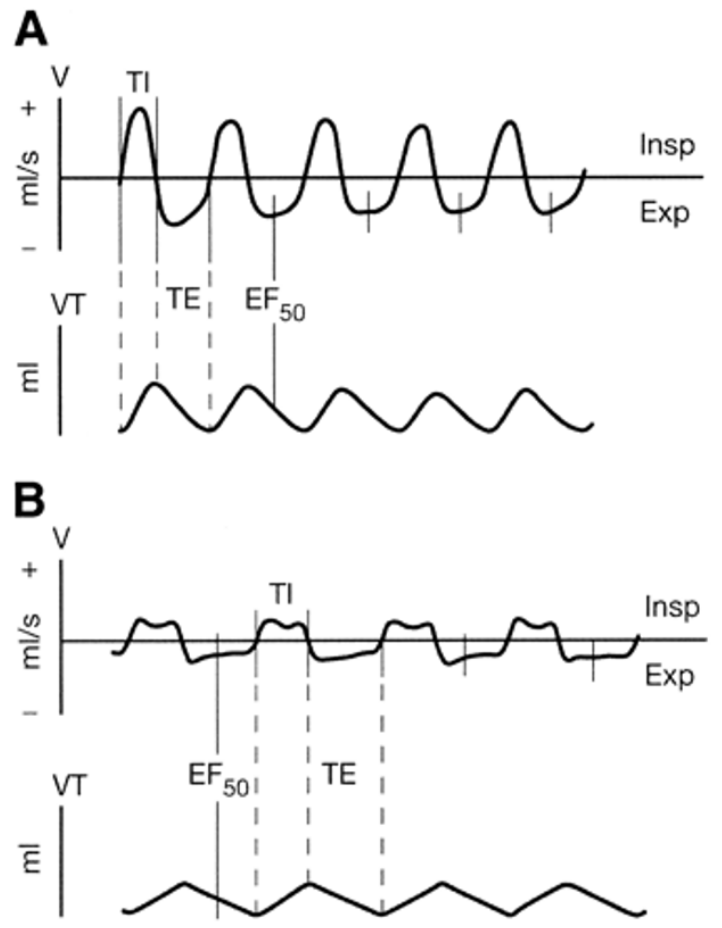

\section{Figure 4}

Characteristic modifications to the normal breathing pattern in conscious BALB/c mice. A: normal breathing pattern of $B A L B / c$ mice breathing room air. $B$ : characteristic pattern of airway obstruction during aerosol challenge with $\mathrm{MCh}$, illustrating the decline in $\mathrm{EF}_{50}$. $A$ and $B$, top tracings: pneumotachograph airflow signals. $A$ and $B$, bottom tracings: corresponding integrated VT signal. A horizontal line at zeroflow separates inspiratory (Insp; upward; +) from expiratory (Exp; downward; -) airflow. V, tidal flow. VT, tidal volume. TI, time of inspiration. TE, time of expiration. Figure taken from [49] with permission.

toxicologic agents [31,39,48-54]. Advantages of this approach are its noninvasiveness and its allowing simple, rapid and repeatable measurements of several conscious animals at a time. Moreover, $\mathrm{EF}_{50}$ is based on physiological principles and has a physical meaning $[\mathrm{ml} / \mathrm{s}]$ that is directly related to airway resistance, thus enabling quantitative interpretation of airway changes between animals [55]. In principle, head-out body plethysmography as described by Alarie et al. also enables evaluation of the sensory irritation potential of inhaled agents by recording the prolongation of the postinspiratory pause in mice $[48,51]$.

Concerns include the uncertainty about the potential contribution of upper airway resistance. To minimize effects 
of restraint stress on responses, monitoring of respiratory function should not be started until animals and individual measurements have settled down to a stable level. Because it has been shown that $\mathrm{EF}_{50}$ may underestimate the magnitude of bronchoconstriction $[9,10]$ it is still unclear how much this limits its use in detecting less pronounced changes in airway hyperresponsiveness. Accordingly, when such circumstances are present, $\mathrm{EF}_{50}$ measurements should be confirmed by more direct assessments of pulmonary resistance. Table 3 summarizes the pros and cons of $\mathrm{EF}_{50}$ measurements.

\section{Conclusion}

In this manuscript we have tried to provide a review of the advantages and disadvantages of different methods of assessing pulmonary function in mice. Although mice may be far from perfect models of human lung disease, the advantages of using mouse models has made them the choice for many experimental studies, e.g. experimental asthma. In these models measuring lung function and particularly airway responsiveness is a major outcome parameter. To this end it is critically important to have suitable methods of phenotyping lung function. Although many of the methodologies for measuring pulmonary function have been developed, there are important limitations and considerations such as expertise, technical difficulty of the procedure, and costs, which should be recognized when applying them in the mouse. Unfortunately, at the present time, there is no gold standard for measuring lung function in mice, since none of the available methods is optimal in all regards. Some investiga- tions require more detailed measurement of the individual mechanical properties, and these studies normally require invasive determination of pulmonary mechanics. The ability to make longitudinal measurements in intact conscious mice, however, allows investigators to make use of more powerful statistics with smaller numbers of animals. We have discussed the merits of several of these approaches that may be useful for investigators requiring this approach. In particular in situations where the measurements are applied to develop a potential therapeutic or clinical trial design, these should always be confirmed by the more conservative invasive methodologies.

\section{Abbreviations (Table 4) \\ Competing interests}

The author(s) declare that they have no competing interests.

\section{Authors' contributions}

TG and CT conceived of the review and drafted the manuscript, $\mathrm{AB}$ helped to draft the manuscript, WM helped to draft, discuss and revise the manuscript. All authors read and approved the final manuscript.

\section{Acknowledgements}

We gratefully thank Christina Nassenstein, MD, PhD, ITEM Hannover, for technical support and Hannelore Ryland, Hannover Medical School, for the illustrations.

Table 4:

\begin{tabular}{|c|c|c|}
\hline Parameter & Abbr. & Description \\
\hline lung resistance & $\mathrm{R}_{\mathrm{L}}$ & $\begin{array}{l}\text { quantitatively assesses the level of obstruction in the lungs and comprises the resistance of the conducting } \\
\text { airways }\left(R_{a w}\right) \text { and tissue }\left(R_{t i}\right)\end{array}$ \\
\hline lung conductance & $\mathrm{G}_{\mathrm{L}}$ & reciprocal of lung resistance $\left(I / R_{L}\right)$ \\
\hline dynamic compliance & $\mathrm{C}_{\text {dyn }}$ & $\begin{array}{l}\text { primarily reflects the elasticity of the lung parenchyma, but is also affected by surface tension, smooth muscle } \\
\text { constriction, and peripheral airway inhomogeneities. In contrast, static compliance is measured at true } \\
\text { equilibrium, when resistances and compliances are not uniform throughout the lung, e.g. in the absence of any } \\
\text { motion. }\end{array}$ \\
\hline methacholine & $\mathrm{MCh}$ & non-specific cholinergic bronchoconstrictor used to assess airway responsiveness \\
\hline elastance & $\mathrm{E}$ & captures the elastic rigidity of the lungs. \\
\hline reactance & $\mathrm{X}$ & reflects respiratory compliance (I/elastance) and characterizes the lung parenchyma \\
\hline input impedance & Z & expresses the combined effects of resistance, compliance and inertance as a function of frequency. \\
\hline inertance & 1 & $\begin{array}{l}\text { represents the inertive properties of the gases in the airways. The majority of I resides in the central airways } \\
\text { bypassed by the tracheal cannula. Inertance can be ignored in the mouse below } 20 \mathrm{~Hz} \text {. }\end{array}$ \\
\hline tissue damping & G & is closely related to tissue resistance and reflects the dissipative properties of the lung tissues. \\
\hline tissue elastance & $\mathrm{H}$ & reflects the elastic properties of the lung tissues. \\
\hline enhanced pause & Penh & $\begin{array}{l}\text { is a unitless, empirical measurement derived from box pressure signals during inspiration and expiration and } \\
\text { the timing comparison of early and late expiration and is used as a non-invasive measure of } \\
\text { bronchoconstriction. }\end{array}$ \\
\hline $\begin{array}{l}\text { tidal midexpiratory } \\
\text { flow }\end{array}$ & $\mathrm{EF}_{50}$ & $\begin{array}{l}\text { is defined as the tidal flow at the midpoint of expiratory tidal volume and is used as a non-invasive measure of } \\
\text { airway constriction. }\end{array}$ \\
\hline $\begin{array}{l}\text { positive end- } \\
\text { expiratory pressure }\end{array}$ & PEEP & $\begin{array}{l}\text { is the amount of pressure above atmospheric pressure present in the airway at the end of the expiratory } \\
\text { cycle. PEEP improves gas exchange by preventing alveolar collapse, recruiting more lung units, and increasing } \\
\text { functional residual capacity. }\end{array}$ \\
\hline
\end{tabular}




\section{References}

I. Taube C, Dakhama A, Gelfand EW: Insights into the pathogenesis of asthma utilizing murine models. Int Arch Allergy Immunol 2004, I 35:173-186.

2. Kips JC, Anderson GP, Fredberg J], Herz U, Inman MD, Jordana M, Kemeny DM, Lotvall J, Pauwels RA, Plopper CG, Schmidt D, Sterk PJ, Van Oosterhout AJ, Vargaftig BB, Chung KF: Murine models of asthma. Eur Respir J 2003, 22:374-382.

3. Kumar RK, Foster PS: Modeling allergic asthma in mice. Pitfalls and opportunities. Am J Respir Cell Mol Biol 2002, 27:267-272.

4. Irvin CG, Bates JH: Measuring the lung function in the mouse: the challenge of size. Respir Res 2003, 4:4.

5. Drazen JM, Finn PW, De Sanctis GT: Mouse models of airway responsiveness: physiological basis of observed outcomes and analysis of selected examples using these outcome indicators. Annu Rev Physiol 1999, 6 I:593-625.

6. Rao S, Verkman AS: Analysis of organ physiology in transgenic mice. Am J Physiol Cell Physiol 2000, 279:CI-CI8.

7. Lorenz JN: A practical guide to evaluating cardiovascular, renal, and pulmonary function in mice. Am J Physiol Regulatory Integrative Comp Physiol 2002, 282:RI565-I582.

8. Bates JH, Irvin CG: Measuring lung function in mice: the phenotyping uncertainty principle. J Appl Physiol 2003, 94: I297-I306.

9. Glaab T, Ziegert M, Baelder R, Korolewitz R, Braun A, Hohlfeld JM, Mitzner W, Krug N, Hoymann HG: Invasive versus noninvasive measurement of allergic and cholinergic airway responsiveness in mice. Respir Res 2005, 6:139.

10. Glaab T, Mitzner W, Braun A, Ernst H, Korolewitz R, Hohlfeld JM, Krug N, Hoymann HG: Repetitive measurements of pulmonary mechanics to inhaled cholinergic challenge in spontaneously breathing mice. J Appl Physiol 2004, 97: I I04- I I I I.

II. Peslin R, Fredberg J]: Oscillation mechanics of the respiratory system. In Handbook of Physiology. The Respiratory System Volume III. Issue I Edited by: Macklem PT, Mead J. Bethesda: American Physiological Society; 1986: I45-I78.

12. Hoymann HG: Invasive and noninvasive lung function measurements in rodents. J Pharmacol Toxicol Methods 2007, 55:16-26.

13. Lofgren JLS, Mazan MR, Ingenito EP, Lascola K, Seavey M, Walsh A Hoffman AM: Restrained whole body plethysmography for measure of strain-specific and allergen-induced airway responsiveness in conscious mice. I Appl Physiol 2006, I 0 I: | 495-1505.

14. Martin TR, Gerard NP, Galli SJ, Drazen JM: Pulmonary responses to bronchostrictor agonists in the mouse. J Appl Physiol 1988, 64:2318-2323

15. Sly PD, Collins RA, Thamrin C, Turner DJ, Hantos Z: Volume dependence of airway and tissue impedances in mice. J Appl Physiol 2003, 94:1460-|466.

16. Vinegar A, Sinnett EE, Leith DE: Dynamic mechanism determine functional residual capacity in mice, Mus Musculus. J Appl Physiol 1979, 46:867-87I.

17. Takeda K, Hamelmann E, Joetham A, Shultz LD, Larsen GL, Irvin CG, Gelfand EW: Development of eosinophilic airway inflammation and airway hyperresponsiveness in mast-cell deficient mice. J Exp Med 1997, I 86:449-454

18. Taube C, Duez C, Cui ZH, Takeda K, Rha YH, Park JW, Balhorn A, Donaldson DD, Dakhama A, Gelfand EW: The role of IL-I3 in established allergic airway disease. J Immunol 2002, I 69:6482-6489.

19. Brown RH, Walters DM, Greenberg RS, Mitzner W: A method of endotracheal intubation and pulmonary functional assessment for repeated studies in mice. I Appl Physiol 1999, 87:2362-2365

20. Polte T, Foell J, Werner C, Hoymann HG, Braun A, Burdach S, Mittler RS, Hansen G: CDI37-mediated immunotherapy for allergic asthma. I Clin Invest 2006, I | 6:1025-1036.

21. Tarnavski O, McMullen JR, Schinke M, Nie Q, Kong S, Izumo S: Mouse cardiac surgery: comprehensive techniques for the generation of mouse models of human diseases and their application for genomic studies. Physiol Genomics 2004, 16:349-360

22. Zhao $H$, Mitzner $W$ : An improved, simplified method for mouse intubation [abstract]. Am J Respir Crit Care Med 2004, 169:A293.
23. Roy R, Powers SR Jr, Kimball WR: Estimation of respiratory parameters by the method of covariance ratios. Comp Biomed Res 1974, 7:21-39.

24. Walters DM, Wills-Karp M, Mitzner W: Assessment of cellular profile and lung function with repeated bronchoalveolar lavage in individual mice. Physiol Genomics 2000, 2:29-36.

25. Schuessler TF, Bates JHT: A computer-controlled research ventilator for small animals: design and evaluation. IEEE Trans Biomed Eng 1995, 42:860-866.

26. Irvin CG, Peslin R: Methods for measuring total respiratory impedance by forced oscillations. Bull Eur Physiopathol Respir 1986, 22:62|-63|.

27. Hantos Z, Daroczy B, Suki B, Nagy S, Fredberg J): Input impedance and peripheral inhomogeneity of dog lungs. J Appl Physiol 1992, 72: $168-178$.

28. Tomioka S, Bates JHT, Irvin CG: Airway and tissue mechanics in a murine model of asthma: alveolar capsule vs. forced oscillations. J Appl Physiol 2002, 93:263-270.

29. Hantos Z, Collins RA, Turner DJ, Janosi TZ, Sly PD: Tracking of airway and tissue mechanics during TLC maneuvers in mice. Appl Physiol 2003, 95:1695-1705.

30. Bozanich EM, Collins RA, Thamrin C, Hantos Z, Sly PD, Turner DJ: Developmental changes in airway and tissue mechanics in mice. J Appl Physiol 2005, 99:108-II3.

31. Petak F, Habre W, Donati YR, Hantos Z, Barazzone-Argiroffo C: Hyperoxia-induced changes in mouse lung mechanics: forced oscillations vs. barometric plethysmography. J Appl Physiol 2001, 90:2221-2230.

32. Wagers SS, Haverkamp HC, Bates JHT, Norton RJ, ThompsonFigueroa JA, Sullivan MJ, Irvin CG: Intrinsic and antigen-induced airway hyperresponsiveness are the result of diverse physiological mechanisms. J Appl Physiol 2007, I 02:22 I-230.

33. Kitagaki K, Businga TR, Racila D, Elliott DE, Weinstock JV, Kline JN: Intestinal helminths protect in a murine model of asthma. Immunol 2006, I77:1628-1635.

34. Bates $\mathrm{J}$, Mitzner $\mathrm{W}$ : Point : counterpoint lung impedance measurements are/are not more useful than simpler measurements of lung function in animal models of pulmonary disease. J Appl Physiol 2007. PMID: I7431089

35. Hamelmann E, Schwarze J, Takeda K, Oshiba A, Larsen GL, Irvin CG Gelfand EW: Noninvasive measurement of airway responsiveness in allergic mice using barometric plethysmography. Am J Respir Crit Care Med 1997, I 56:766-775.

36. Chong BT, Agarwal DK, Romero FA, Townley RG: Measurement of bronchoconstriction using whole-body plethysmograph: comparison of freely moving versus restrained guinea pigs. Pharmacol Toxicol Methods 1998, 39:163-168.

37. Kumar RK, Hebert C, Webb DC, Li L, Foster PS: Effects of anticytokine therapy in a mouse model of chronic asthma. Am J Respir Crit Care Med 2004, I 70: 1 043-1048.

38. Hansen G, Berry G, DeKruyff RH, Umetsu DT: Allergen-specific ThI cells fail to counterbalance Th2 cell-induced airway hyperreactivity but cause severe airway inflammation. J Clin Invest 1999, 103:175-183.

39. Finotto S, De Sanctis GT, Lehr HA, Herz U, Buerke M, Schipp M, Bartsch B, Atreya R, Schmitt E, Galle PR, Renz H, Neurath MF: Treatment of allergic airway inflammation and hyperresponsiveness by antisense-induced local blockade of GATA-3 expression. J Exp Med 2001, 193: 1247-1260.

40. Adler A, Cieslewicz G, Irvin CG: Unrestrained plethysmography is an unreliable measure of airway responsiveness in $B A L B / C$ and C57BL/6 mice. J Appl Physiol 2004, 97:286-292

41. Lundblad LKA, Irvin CG, Adler A, Bates JHT: A reevaluation of the validity of unrestrained plethysmography in mice. J Appl Physiol 2002, 93: I I 98-1 207

42. Albertine KH, Wang L, Watanabe S, Marathe GK, Zimmerman GA, Mclntyre TM: Temporal correlation of measurements of airway hyperresponsiveness in ovalbumin-sensitized mice. $\mathrm{Am} J$ Physiol Lung Cell Mol Physiol 2002, 283:L219-L233.

43. Bates J, Irvin C, Brusasco V, Drazen J, Fredberg J, Loring S, Eidelman D, Ludwig M, Macklem P, Martin J, Milic-Emili J, Hantos Z, Hyatt R, Lai-Fook S, Leff A, Solway J, Lutchen K, Suki B, Mitzner W, Pare P, Pride N, Sly P: The use and misuse of Penh in animal models of lung disease. Am J Respir Cell Mol Biol 2004, 31:373-374.

44. Mitzner W, Tankersley C: Interpreting Penh in mice. J Appl Physiol 2003, 94:828-83I. 
45. Sly PD, Turner DJ, Collins RA, Hantos Z: Penh is not a validated technique for measuring airway function in mice. Am J Respir Crit Care Med 2005, I 72:256.

46. Hessel EM, Zwart A, Oostveen E, Van Oosterhout AJ, Blyth DI, Nijkamp FP: Repeated measurement of respiratory function and bronchoconstriction in unanesthetized mice. J Appl Physiol 1995, 79:17|I-17|6

47. Flandre TD, Leroy PL, Desmecht DJ: Effect of somatic growth, strain, and sex on double-chamber plethysmographic respiratory function values in healthy mice. J Appl Physiol 2003, 94:1I29-1136.

48. Vijayaraghavan R, Schaper M, Thompson R, Stock MF, Boylstein LA, Luo JE, Alarie $Y$ : Computer assisted recognition and quantitation of the effects of airborne chemicals acting at different areas of the respiratory tract in mice. Arch Toxicol 1994, 68:490-499.

49. Glaab T, Daser A, Braun A, Steinmetz-Neuhaus U, Fabel H, Alarie $Y$, Renz $\mathrm{H}$ : Tidal midexpiratory flow as a measure of airway hyperresponsiveness in allergic mice. Am J Physiol Lung Cell Mol Physiol 200I, 280:L565-L573.

50. Path G, Braun A, Meents N, Kerzel S, Quarcoo D, Raap U, Hoyle GW, Nockher WA, Renz H: Augmentation of allergic earlyphase reaction by nerve growth factor. Am J Respir Crit Care Med 2002, 166:818-826.

5I. Nassenstein C, Dawbarn D, Pollock K, Allen SJ, Erpenbeck VJ, Spies $\mathrm{E}$, Krug N, Braun A: Pulmonary distribution, regulation, and functional role of Trk receptors in a murine model of asthma. J Allergy Clin Immunol 2006, I I 8:597-605.

52. Voswinckel R, Motejl V, Fehrenbach A, Wegmann M, Mehling T, Fehrenbach H, Seeger W: Characterisation of post-pneumonectomy lung growth in adult mice. Eur Respir J 2004, 24:524-532.

53. Sausbier M, Zhou XB, Beier C, Sausbier U, Wolpers D, Maget S, Martin C, Dietrich A, Ressmeyer AR, Renz H, Schlossmann J, Hofmann F, Neuhuber W, Gudermann T, Uhlig S, Korth M, Ruth P: Reduced rather than enhanced cholinergic airway constriction in mice with ablation of the large conductance $\mathrm{Ca2+-activated}$ K+ channel. FASEB J 2007, 2 1:812-822.

54. Baelder R, Fuchs B, Bautsch W, Zwirner J, Köhl J, Hoymann HG, Glaab T, Erpenbeck V, Krug N, Braun A: Pharmacological targeting of anaphylatoxin receptors during the effector phase of allergic asthma suppresses airway hyperresponsiveness and airway inflammation. J Immunol 2005, 174:783-789.

55. Hantos Z, Brusasco V: Assessment of respiratory mechanics in small animals: the simpler the better? J Appl Physiol 2002, 93: II96-II 97

Publish with Bio Med Central and every scientist can read your work free of charge

"BioMed Central will be the most significant development for disseminating the results of biomedical research in our lifetime. "

Sir Paul Nurse, Cancer Research UK

Your research papers will be:

- available free of charge to the entire biomedical community

- peer reviewed and published immediately upon acceptance

- cited in PubMed and archived on PubMed Central

- yours - you keep the copyright
BiolMedcentral 